Vol.45, N. 2 : pp. 223 - 232, June 2002 ISSN 1516-8913 Printed in Brazil
BRAZILIAN ARCHIVES OF BIOLOGY AND TECHNOLOGY

AN INTERNATIONAL JOURNAL

\title{
Diet of Astyanax species (Teleostei, Characidae) in an Atlantic Forest River in Southern Brazil
}

\author{
Fábio Silveira Vilella*; Fernando Gertum Becker and Sandra Maria Hartz \\ Laboratório de Ecologia de Vertebrados; Departamento e Centro de Ecologia; Universidade Federal do Rio \\ Grande do Sul; Av. Bento Gonçalves, 9500; Caixa Postal 15007; CEP 91501-970; Porto Alegre - RS - Brasil
}

\begin{abstract}
Feeding habits of six species of Astyanax from river Maquiné are described. Fishes were sampled bi-monthly from November/95 to September/96 in two zones of the river. Items were identified, counted and had their abundance estimated according to a semi-quantitative scale. Frequency of occurrence, alimentary importance index (IFI) values and a similarity analysis of diets for each species-river zone sample were examined. All the species were considered typically omnivorous, with insects and vegetal matter being the most important items in their diet. These species could act as seed dispersers, particularly for macrophytes. Intra-specific spatial differences were not observed in comparisons of samples from two diferent regions of the river, except for $\underline{A}$. fasciatus. The presence of Podostemaceae macrophytes in the mid-course of the river seemed to be important both as an autochthonous food resource and as habitat for several organisms preyed by the Astyanax species.
\end{abstract}

Key words: Diet, seed dispersal, fish, Astyanax, Atlantic Forest, Brazil

\section{INTRODUCTION}

The Atlantic Forest includes a large region in eastern Brazil, from the state of Rio Grande do Norte (north) to Rio Grande do Sul (south). It is one of the most biodiverse and endangered ecosystems in the world (Myers et al. 2000). Threats to the Atlantic Forest ecosystems include the degradation of natural streams and rivers caused by loss of riparian vegetation, erosion, siltation, organic and chemical pollution, sand mining, damming and introductions of exotic species (Menezes et al., 1990; Faria and Marques, 1999). Many stream fishes have been particularly affected by alterations in the forest ecosystem because it influenced light incidence, turbidity,
$\mathrm{pH}$, temperature and food resources (Menezes et al., 1990; Uieda and Kikuchi, 1995).

Fishes are probably the less known vertebrates in the Atlantic Forest, partly due to a lack of taxonomic and systematic information, but also because there are not many field studies (Rosa and Menezes, 1996). Most ecological investigations are restricted to the states of São Paulo and Rio de Janeiro (Uieda, 1984; Sazima, 1986; Costa, 1987; Menezes et al., 1990; Sabino and Castro, 1990 and Uieda et al., 1997).

Several fish species represent important links between aquatic and terrestrial trophic webs (Gelwick and Matthews, 1996) as predators or preys, but can also act as seed dispersers (Goulding et al., 1988; Crampton, 1999). The role

${ }^{*}$ Author for correspondence 
of fish as predators or seed dispersers can be investigated by stomach content analysis.

In the Atlantic Forest, the relationship between fish and the forest has rarely been studied (Menezes et al, 1990; Uieda and Kikuchi, 1995). Some of the most common species in this ecosystem belong to the characid genus Astyanax Baird and Girard, 1854, which includes many species with Neotropical distribution and uncertain taxonomic situation (Jin and Toledo, 1975; Moreira-Filho and Bertollo, 1991; Garutti and Britski, 1997). There are several studies about the feeding habits of Astyanax species (Zaret and Rand, 1971; Barbosa and Matsumura-Tundisi, 1984; Costa, 1987; Teixeira, 1989; Arcifa et al, 1991; Esteves and Galetti Jr., 1995; Meschiatti,
1995; Esteves, 1996; Hartz et al., 1996; Uieda et al., 1997; Fugi, 1998 and Luiz et al., 1998) and it seems be consensual that Astyanax are opportunistic feeders with a highly variable diet composition.

This work describes the diet of the six Astyanax species found in Maquiné River, indicating their trophic roles and discussing their connections with the terrestrial environment. It also examines the hypothesis that because of the opportunistic character of these species, their diet would be different in the potamal and rithral zones of the river, where habitat conditions and biota are determined by physiographic conditions (Vannote et al., 1980; Baptista et al, 1998a; b).

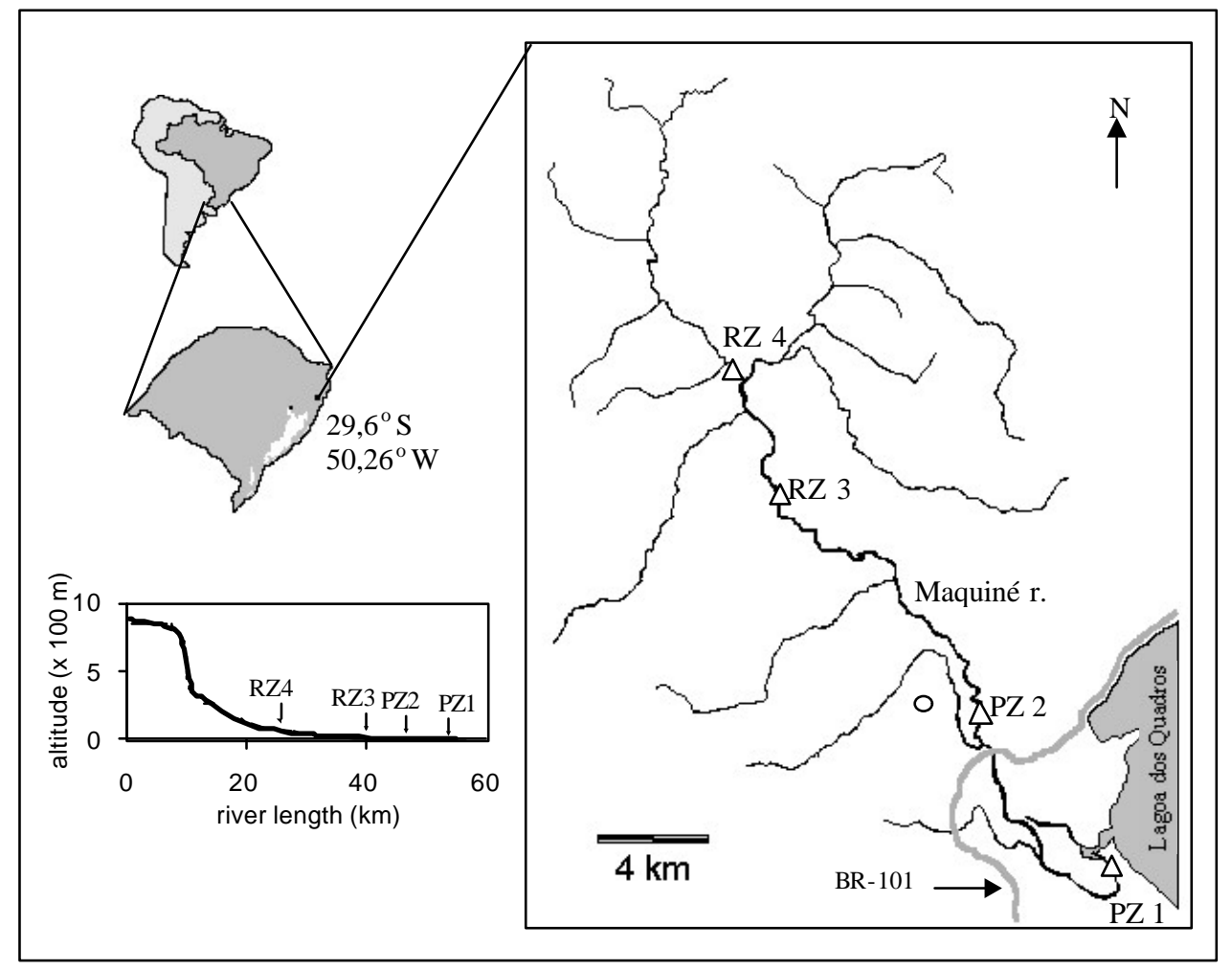

Figure 1 - Geographic situation of the Maquiné river drainage showing location of the sampling points (open circle $=$ city of Maquiné). In the lower left corner, the position of the sampling points on the longitudinal profile of the river is shown.

\section{MATERIALS AND METHODS}

The Maquiné River watershed (approximately $29.6^{\circ} \mathrm{S} 50.26^{\circ} \mathrm{W}$; Figure 1) is part of the Tramandaí River basin in northeastern Rio Grande do Sul. The headwaters are situated in the Serra Geral highlands (maximum altitude around $900 \mathrm{~m}$ ) and the water runs approximately $50 \mathrm{~km}$ until Lagoa dos Quadros (altitude $<10 \mathrm{~m}$ ), a freshwater lake in the Coastal Plain region.

Sampling occurred in two main zones of the river: the potamal zone and the rithral zone. The potamal zone (PZ) is situated in the lowlands of the Coastal Plain region, where the river is deeper and wider, 
water transparency is low, channel bed is formed by sandy and silty substrates, and several types of macrophytes are abundant. In this area, a large volume of water flows slowly towards the river mouth and water level fluctuations usually occur within a period of weeks to months, flooding the surrounding lowlands. The rithral zone (RZ) is situated in an area of higher altitudes and slopes. In this area, the river presents a riffle-pool structure, with high water transparency, rocky bottoms and lower abundance and richness of macrophytes. Water level fluctuations can occur within a period of hours to days.

Samples were obtained every two months, from November/1995 to September/1996. Four river reaches were sampled, two in the potamal zone (PZ1 and PZ2) and two in the rithral zone (RZ3 and RZ4). Fish were captured with gillnets exposed for 24 hours (except RZ4), seine nets, cast nets and dip nets, preserved in $10 \%$ formaline and then transferred to ethanol $(70 \%$.). Voucher specimens were deposited at Science Museum, Pontifícia Universidade Católica do Rio Grande do Sul (MCPUCRS).

Only full stomachs from adult specimens were examined (partially full stomachs were not considered). Food items where identified to the best possible taxonomic resolution. Abundance of each food item in a stomach was estimated by a semi-quantitative method, where abundance corresponded to categories representing the proportional area occupied by the item in relation to the total area occupied by all items. Four categories were defined following Guillen and Granado (1984): 0 - absent; 1 - rare $(<25 \%$ of the area of all items); 2 - abundant (25 to $50 \%$ of the area of all items) and 3 - very abundant (> 50\% of the area of all items).

The importance of an item in the diet of each species was estimated by an index of food importance (IFI), which represents the relation between frequency of occurrence of that item (Hyslop, 1980) and its abundance. The IFI proposed by Granado-Lorencio and Garcia-Novo (1986) is calculated as

$$
\mathrm{IFI}=\frac{\sum\left(\mathrm{X}_{\mathrm{k}} \cdot \frac{\mathrm{k})}{\mathrm{a}-1}\right.}{1}
$$

Where:

$\mathrm{a}=$ number of categories;

$X_{k}=$ frequency of the item $X_{i}$ with $k$ value of abundance; $\mathrm{k}=$ categorie of abundance.

The IFI value for each item varies from zero to one. Rare items have values lower than 0.15, additional items present values between 0.15 and 0.3 , and main items present values equal or higher than 0.3 .

Samples from the potamal zone (PZ1 and PZ2) and rithral zone (RZ3 and RZ4) were pooled for investigating diet variations in relation to the different regions of the river. Diet similarity among species and different river zone samples was examined by cluster analysis based on a correlation matrix for de IFI. In this analysis, each species sample from a particular river zone (e.g. A. bimaculatus from the rithral zone or $A$. bimaculatus from the potamal zone) was considered an Operational Taxonomic Unit (OTU). A Principal Coordinates Analysis (PCO) was employed to detect which food items were determinant in the formation of the identified clusters. Both analyses were processed in the software MULTIV (Pillar, 1997). In the graphical plot of the PCO analysis including all food categories, all the OTUs (except for A. alburnus) were clustered right on the $\mathrm{PCO} 2$, resulting in an unclear display. We re-ran this analysis without the food category "rests of insects" because of its potentially confounding effect on the process of analysis and interpretation. The result showed no major alterations but improved the graphic display of OTUs, so we used this procedure for analyzing the data.

\section{RESULTS}

Six species of Astyanax were captured during the study period: A. alburnus (Aa), A. bimaculatus (Ab), A. eigenmanniorum (Ae), A. fasciatus (Af), A. scabripinnis (Ay) and Astyanax sp. (As). All species were captured regularly in both the potamal and rithral zones, except for A. alburnus, which is typically a lowland species and $A$. scabripinnis which is typically a headwater species. This species was not considered in the cluster and PCO analysis because of the low number of individuals captured.

Table 1 lists the food items present in the stomachs of the six species in each zone of the river, with the respective values for frequency of occurrence and IFI. Astyanax alburnus showed the richest diet (25 food items) among all studied species (up to 
eight items were found in a single stomach). Such richness of items was possibly influenced by the larger sample of stomachs examined for this species. The remaining species consumed from 15 (A. bimaculatus) to 19 (A.fasciatus) different food items. The maximum number of items observed in a single stomach was 10 for A. fasciatus and 7 for the remaining species. For all species (except $A$. alburnus), between 40 and $60 \%$ of the total number of items occurred in stomachs from both the potamal zone (PZ) and the rithral zone (RZ). Overall, the studied Astyanax species could be considered as omnivorous, preying on a variety of items, with insects and plant matter representing the most important animal and plant food items respectively.

The results of the cluster analysis for diet similarity among species and different river zones are presented in Figure 2. Three main groups can be observed, with A. alburnus alone in one cluster and the other species in the remaining two clusters. Except for A. fasciatus, all species presented similar diet in both river zones, indicating that differences of habitat and biota among the potamal and rithral zones did not influence the main diet characteristics of most Astyanax species.

The Principal Coordinates Analysis (Figure 3, Table 2) allowed the identification of the most important food items characterizing the diets of each species in each region of the river. The resultant ordination of OTU in three groups was concordant with the cluster analysis. In PCO1, which accounted for $44,4 \%$ of the variation in the data, species were ordinated according to the importance of Collembola, Copepoda, Amphipoda and plant debris. Among these, the first three (which are all animal items) were consumed almost exclusively by $A$. alburnus, while plant debris were of low importance for this species. The importance of microcrustacea (Copepoda and Amphipoda) and the low importance of plant debris were distinctive features in the diet of $A$. alburnus relative to the other Astyanax from Maquiné River.

In PCO2 $(20.65 \%$ of variation in the data), ordination was mainly influenced by the consumption of Diptera. Species where consumption of Diptera was more important relative to other items, appeared in the lower group, while those where Diptera was less important were in the upper group.

Astyanax alburnus could be considered an omnivorous species with a marked tendency to carnivory because Collembola was the most frequent and abundant item (a main food item) and additional items included only animal organisms (Diptera, Amphipoda and Copepoda). The remaining Astyanax species were typically omnivorous because plant debris, algae and animal were always additional or main items, with differences among their diets being mainly related to the distinct importance of Diptera. More subtle differences could be discussed from data in Table 1.

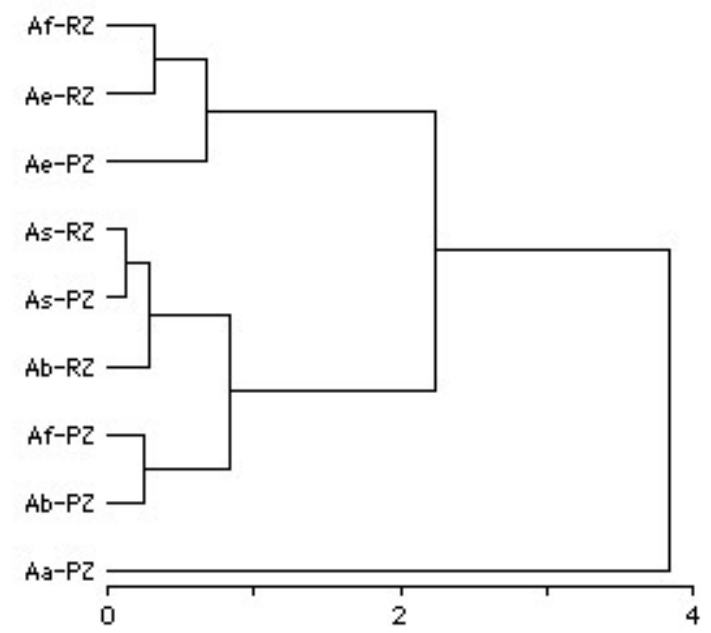

Figure 2 - Cluster analysis for diet similarity of five Astyanax species collected in two different zones of river Maquiné. Aa - Astyanax alburnus; Ab-A. bimaculatus; Ae - A. eigenmanniorum; Af - A. fasciatus; As - A. sp.PZpotamal zone; RZ - rithral zone.

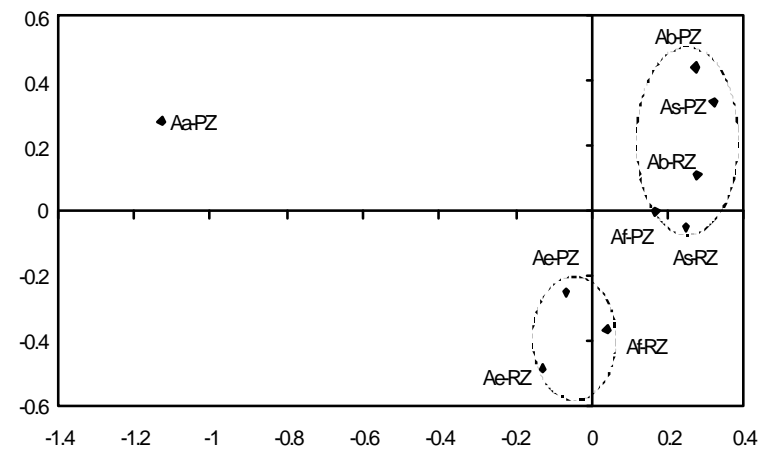

Figure 3 - Principal Coordinates Analysis on diet data of the Astyanax species from two different zones of river Maquiné. Aa - Astyanax alburnus; Ab - A. bimaculatus; Ae - A. eigenmanniorum; Af - A. fasciatus; As - Astyanax $s p$; PZ -potamal zone; RZ - rithral zone.

\section{DISCUSSION}

Astyanax species are not distributed evenly along the river. A. alburnus was practically limited to the 
potamal zone (a few individuals were captured in a single opportunity in RZ3). A. scabripinnis, besides being rare in the samples, appeared only in the rithral zone (RZ). A. bimaculatus and Astyanax sp. were common along the river, $A$. eigenmanniorum was more abundant in the potamal zone (PZ) and A. fasciatus in the rithral zone (RZ). These differences in species distribution and abundance influenced the corresponding number of stomachs examined for each zone of the river. As opportunistic fish, it could be expected that the diet of Astyanax would change from potamal to rithral zone because of differences in habitat and food resource availability. However, the cluster analysis showed that except for A. fasciatus, most Astyanax presented similar diets in the two different zones of the river, indicating that the general trophic role of each species remained the same. Clearly, this result was influenced by the taxonomic resolution employed in food category assignment, but this was also a matter of study objectives. Some differences in diet among species and between the two river zones are mentioned and discussed below, but no consistent and evident change of trophic role could be determined.

Although fish are known to have adaptable and versatile feeding habits, species classification according to the main trophic function is important in community studies (Austen et al., 1994). Astyanax are usually omnivorous fish (Nomura, 1975; Sazima, 1986; Teixeira, 1989; González et al., 1986; Escalante, 1992; Esteves, 1996; Meschiatti, 1995 and Hartz et al., 1996) and, as shown above, this is true for the Astyanax species from Maquiné River.

As mentioned above, the degree of resolution employed in determining food categories influences the results, and can lead to an overestimation of diet overlap (Sabino and Castro, 1990). However, detailed examination of diet composition allowed the identification of specific characteristic features not apparent from the cluster and PCO analyses.

A. alburnus is an insectivore-zooplanktivore species, preying basically on Collembola, Amphipoda, Copepoda and Diptera. The same was observed for A. alburnus in a coastal lake (Hartz et al., 1996), but with Cladocera as main item. Aquatic Collembola live associated to macrophytes and can be found in their leaves or submerged roots. In PZ1, there are large banks of Eichornia spp and flooded margins with
Graminae, where A. alburnus probably have foraged close to the water surface and to the macrophyte roots. This is also indicated by the frequency of pupal and adult Diptera in its stomachs. However, the importance of Amphipoda and sediment (which can be related both to the macrophyte roots and to substrate), and of zooplanktonic Copepoda (particularly Ciclopoida and copepodits) suggests that $A$. alburnus explores the whole water column. Non-identified cysts were also an additional item. Although it could not be precisely identified, this item is certainly from animal origin. In a single stomach it was possible to identify similar cysts as mollusks of the family Hyriidae (Bivalvia), in young life stages. The Hyriidae are obligate fish parasites in their initial life stages.

A. bimaculatus seemed to be a more herbivore species, since plant debris was a main item both in the potamal and rithral zones. Similar observation was made by Luiz et al. (1998), who observed that in the lower course of two streams from the Paraná basin, A. bimaculatus preyed basically on algae, while in headwaters it preyed on higher plants debris. Nevertheless, slight differences in diet between the potamon and the rithron can be observed in Table 1. In the potamal zone, plant debris (mainly Gramineae and seeds of Cyperaceae) and fish scales were the main items in the diet and only this species preyed on fish, although fish scales were found in all species. In the rithral zone, the contribution of animal items to the diet of $A$. bimaculatus increased both in richness and abundance of items in spite of insects being only additional items. Plant debris were composed of seeds, fruits of Ficus sp (Moraceae), leaves and flowers from riparian vegetation, and rheophilous Podostemaceae (leaves and stalks).

A. eigenmanniorum could be considered a more insectivorous species, specially in the rithral zone, where plant debris presented lower importance and frequency, being partly compensated by an increase in algae importance. In the potamal zone, rests of insects, sediment and plant debris were main items in the diet. Mollusks appeared almost exclusively in this species, in the form of large white and flashy structures with no shell fragments. In one stomach, it was possible to distinguish bivalve larvae. Plant debris were seeds of Ciperaceae and Alistemataceae (Echinodorus sp.), fragments of Gramineae and fruits. Stalks, fruits and seeds of Podostemaceae were also found in the stomachs of A. eigenmanniorum. 
Table 1 - Food items observed in the stomachs of Astyanax species from river Maquiné. Results for species samples from the potamal and rithral zones are presented separately. Values represent IFI and absolute frequency of occurrence ( ) of food items. Aa - Astyanax alburnus; Ab - A. bimaculatus; Ae - A. engenmanniorum; Af - A. fasciatus; As - A. sp; Ay-A. scabripinnis; PZ - potamal zone; RZ - rithral zone. $\mathrm{N}$ - number of stomachs examined.

\begin{tabular}{|c|c|c|c|c|c|c|c|c|c|c|c|}
\hline $\mathrm{N}^{\circ}$ & Item & Aa-PZ & $\mathrm{Ab}-\mathrm{PZ}$ & Ab-RZ & Ae-PZ & Ae-RZ & Af-PZ & Af-RZ & As-PZ & As-RZ & Ay-RZ \\
\hline 1 & Sand & $0,18(42)$ & $0,05(2)$ & $0,08(4)$ & $0,33(14)$ & $0,11(2)$ & $0,14(4)$ & $0,20(13)$ & $0,03(1)$ & $0,07(5)$ & $0,22(2)$ \\
\hline 2 & Algae & $0,10(20)$ & & $0,04(2)$ & $0,07(3)$ & $0,11(2)$ & $0,03(1)$ & $0,42(16)$ & 0,09 (4) & $0,31(11)$ & $0,78(3)$ \\
\hline 3 & Plant materials & $0,03(8)$ & $0,39(6)$ & $0,44(10)$ & $0,30(12)$ & $0,15(4)$ & $0,36(5)$ & $0,39(18)$ & $0,59(15)$ & $0,63(21)$ & $0,11(1)$ \\
\hline 4 & Rotifera & & & & & & 0,03 (1) & & & & \\
\hline 5 & Copepoda & $0,21(47)$ & & & & & $0,08(1)$ & & & & \\
\hline 6 & Cladocera & $0,03(4)$ & & & & & & & & & \\
\hline 7 & Nematoda & & & & $0,02(1)$ & & & & & & \\
\hline 8 & Mollusca & $0,01(1)$ & & & 0,15 (4) & & & & & & \\
\hline 9 & Amphipoda & $0,29(39)$ & $0,08(1)$ & $0,04(1)$ & & & & & & & \\
\hline 10 & Decapoda & $0,01(2)$ & & & $0,20(5)$ & & $0,11(2)$ & & & $0,04(1)$ & \\
\hline 11 & Blattaria & $0,01(1)$ & & & & & & & & & \\
\hline 12 & Coleoptera & 0,09 (19) & $0,08(3)$ & $0,23(9)$ & $0,19(6)$ & $0,08(2)$ & $0,03(1)$ & $0,28(13)$ & $0,08(4)$ & $0,17(10)$ & $0,11(1)$ \\
\hline 13 & Collembola & $0,79(69)$ & & & $0,02(1)$ & & & & & & \\
\hline 14 & Diptera & $0,28(63)$ & 0,03 (1) & $0,15(7)$ & $0,24(10)$ & $0,37(8)$ & $0,25(6)$ & $0,30(20)$ & $0,03(2)$ & $0,15(10)$ & $0,22(2)$ \\
\hline 15 & Ephemeroptera & & $0,05(2)$ & $0,02(1)$ & & 0,07 (2) & $0,03(1)$ & $0,27(14)$ & & $0,07(4)$ & $0,22(2)$ \\
\hline 16 & Hemiptera & $0,03(7)$ & & $0,06(1)$ & & & & & $0,02(1)$ & & \\
\hline 17 & Hymenoptera & $0,05(9)$ & & $0,15(3)$ & $0,02(1)$ & $0,15(4)$ & $0,17(2)$ & $0,03(1)$ & $0,14(5)$ & $0,17(8)$ & \\
\hline 18 & Homoptera & $0,03(7)$ & & & $0,02(1)$ & & $0,06(2)$ & & $0,06(2)$ & & \\
\hline 19 & Lepidoptera & & & $0,02(1)$ & & & & $0,06(4)$ & & $0,03(2)$ & \\
\hline 20 & Plecoptera & $0,01(1)$ & & & & & $0,03(1)$ & $0,14(8)$ & & $0,05(2)$ & $0,33(1)$ \\
\hline 21 & Thysanoptera & $0,01(2)$ & & & & $0,04(1)$ & & $0,02(1)$ & & & \\
\hline 22 & Trichoptera & $0,01(1)$ & & $0,04(2)$ & $0,04(2)$ & 0,04 (1) & & $0,11(7)$ & 0,02 (1) & $0,09(7)$ & $0,11(1)$ \\
\hline 23 & Rests of insects & $0,06(8)$ & $0,23(6)$ & $0,27(8)$ & $0,32(13)$ & $0,59(7)$ & $0,22(6)$ & 0,42 (19) & $0,27(9)$ & $0,24(14)$ & $0,11(1)$ \\
\hline 24 & Insect eggs & & & $0,02(1)$ & & & & $0,05(3)$ & & & \\
\hline 25 & Ácarina & $0,01(3)$ & & & & & & $0,02(1)$ & & & \\
\hline 26 & Araneae & $0,01(3)$ & 0,03 (1) & $0,02(1)$ & & & & & & & \\
\hline 27 & Pisces & $0,01(22)$ & $0,13(3)$ & & & & & & & & \\
\hline 28 & Fish scales & $0,02(4)$ & $0,36(7)$ & $0,19(6)$ & $0,11(6)$ & $0,04(1)$ & $0,22(5)$ & $0,15(9)$ & $0,17(7)$ & $0,03(2)$ & $0,11(1)$ \\
\hline 29 & Cists & $0,26(53)$ & & & $0,04(2)$ & & & & & & \\
\hline 30 & $\mathrm{Ni}$ & $0,03(6)$ & $0,26(6)$ & $0,25(6)$ & $0,11(5)$ & $0,30(4)$ & $0,22(6)$ & $0,09(6)$ & $0,06(4)$ & $0,24(15)$ & $0,22(2)$ \\
\hline & $\mathrm{N}$ & 77 & 13 & 16 & 18 & 9 & 12 & 22 & 22 & 25 & 3 \\
\hline & $\begin{array}{l}\text { Number of } \\
\text { items }\end{array}$ & 24 & 10 & 15 & 15 & 11 & 14 & 15 & 11 & 13 & 10 \\
\hline
\end{tabular}

Table 2 - Results of the Principal Coordinates Analysis on stomach content data of Astyanax species in river Maquiné. Only food items with scores higher than \pm 0.5 in PCO1 and PCO2 are shown.

\begin{tabular}{lclc}
\hline Item & PCO 1 & Item & PCO 2 \\
\hline Cists & -0.9503 & Diptera & -0.7933 \\
Collembola & -0.9390 & Thysanoptera & -0.6555 \\
Cladocera & -0.9351 & Araneae & 0.6400 \\
Blattaria & -0.9351 & Trichoptera & -0.5971 \\
Copepoda & -0.8541 & Pisces & 0.5382 \\
Amphipoda & -0.8532 & Ephemeroptera & -0.5190 \\
Plant materials & 0.8291 & Sand & -0.5026 \\
Acarina & -0.6257 & & \\
Fish scales & 0.5531 & & 0.8371 \\
Diptera & -0.5377 & & 20.651 \\
Ni & 0.5089 & & \\
Eigenvalue & 1.6394 & & \\
\% of variance & 40.444 & & \\
\hline
\end{tabular}

The presence of relatively undigested parts of Podostemaceae in the stomachs from lower course (PZ1) individuals indicates that this species can realize considerable spatial movements along the river. As Podostemaceae are typical from rithral areas, individuals of A. eigenmanniorum probably move from these areas to the lower course, tamal areas in a relatively short period. $A$. eigenmanniorum from Maquiné River was also found to be more insectivorous than the 
populations studied by Escalante (1982) and Teixeira (1989), for which plant debris were the most characteristic food items. Hartz et al. (1996) observed that higher plants were more important in warmer periods of the year, while insects (mainly Diptera) were most important in cooler periods, indicating that seasonal differences must also be investigated. According to their IFI values, the item "rests of insects" was considered a main item in both river zones. It must be noted, however, that this category was composed basically by exoskeleton pieces that should be transformed into small fragments before passing through the intestine. As a result, the importance of insect rests as food was probaly overestimated, because they probably had longer residence period within the stomachs, and were less efficiently digested when compared to "softer" items.

Stomachs of A. fasciatus from the potamal zone contained mainly rests of leaves, flowers and Gramineae, with very low importance to algae. In contrast, algae were a main item in the rithral zone as well as Coleoptera and Ephemeroptera.

Populations of A. fasciatus from reservoirs and floodplain lakes have been found omnivore feeders with a tendency to insect feeding (Esteves and Galetti Jr., 1995; Meschiatti, 1995) and zooplankton feeding (Barbosa and MatsumuraTundisi, 1984). Esteves (1996) observed an ontogenetic shift in the diet of this species, from zooplankton to algae and higher plants. In Maquiné River, only adult specimens were studied and foods from vegetal origin were main items in both zones of the river. Esteves (1996) also states that in rivers A. fasciatus and A. bimaculatus tend to explore the same food resources (algae, higher plants, insects and scales). In Maquiné River, the similarity between the diet of these secies was higher in the potamal zone, while in the rithral zone $A$. fasciatus consumed more algae, sediment and insects (Diptera, Ephemeroptera, Plechoptera and Trichoptera). Astyanax sp from the potamal zone consumed mainly leaves and flowers, especially Gramineae. Starch grains could be observed in some stomachs. Similarly to $A$. fasciatus, in the rithral zone the importance of plant debris and algae was higher for Astyanax sp. However, the low importance of sediment and Diptera make the diet of this species more similar to that of A. bimaculatus.

Fish scales were found in stomachs from all examined Astyanax species and presented higher IFI values in the potamal zone for almost all species. The scales found in the stomachs were usually clustered and firmly bent, and were apparently being digested. Some empty stomachs contained only this clustered mass of scales. The consumption of fish scales by Astyanax species has been observed by other authors (Nomura, 1975; Meschiatti, 1995; Hartz et al. 1996; Uieda et al., 1997), but it is not clear if this is a consequence of behavioral interactions or feeding habits. In underwater observations, it has been observed that individuals preyed on scales deposited on the bottom of river pools (Virgínia Uieda, pers. comm.). However, according to Arcifa et al., 1991, the ingestion of scales could be a consequence of interspecific antagonistic interactions in the larger multispecific schools formed in lentic waters. Whatever the case, fish scales contain about $20 \%$ of the total calcium in the body of some species (Takagi et al. 1989), and may be a source of this element for the fish feeding on them.

Sand was present in the diet of all Astyanax species from the Maquiné river, being a principal item for A. eigenmanniorum in the potamal zone. The frequent presence of this item suggested it might be important in the diet of Astyanax. In the present study, the scale of analysis was not adequate to evaluate this question, but possible reasons for the ingestion of sand are: the consuption of biofilm associated to the sediment, as an auxilliary item for mechanic destruction of plant items or hard parts of insects and crustaceans; or a low efficiency of the gill rakers in avoiding the ingestion of sand with the actual food items. Barbosa and Matsumura-Tundisi (1984)) and Hartz et al. (1996) also observed the presence of sand in the stomachs of Astyanax species, but did not discuss its role as a feeding item.

The importance of allochthonous food sources for stream fishes is well known (Sabino and Zuanon, 1998). According to Uieda and Kikuchi (1995), many stream fish depend primarily on allochthonous materials, preying on terrestrial insects and plant debris. In Maquiné River, allochthonous items are evidently important for Astyanax spp. However, the occurrence of Podostemaceae in riffles represents a notable source of autochthonous food, both in its own and as habitat for macroinvertebrates.

The presence of Podostemaceae was also observed in Amazonian fish stomachs (Santos et al., 1997; Santos and Rosa, 1998), but had not yet been 
mentioned for Atlantic Forest fishes. This plants are typically found in lotic environments, on sandy and rocky substrates being associated to coarse litter from the riparian forest, roots, algae and a wide variety of insects (Santos et al., 1997; Santos and Rosa, 1998). Podostemaceae thus function as an autochthonous food source for fish and aquatic invertebrates, as well as a habitat for larval forms of many insect groups. Philbrick and Novelo (1997) stated that little is known about Podostemaceae seed dispersion by biological vectors, so that the presence of Podostemaceae in the stomachs of Astyanax could have connections with the biology of this plants.

The presence of fruits and seeds in the diet of fish has been recognized in the literature (Gottsberger, 1978; Goulding, 1980; Kubitzki, 1985; Kubitzki and Ziburaki, 1993; Souza-Steveaux et al, 1994; Araújo Lima et al., 1995), which indicated the role of characiforms and siluriforms as the most important fish seed dispersers in Amazonian waters. Because of the presence of apparently intact plant seeds in Astyanax stomachs, it is possible that these fish could act as seed dispersers. Astyanax species are mentioned in the literature as exploratory fish that are able to move along considerable distances along rivers, occupying a variety of habitats (Edwards, 1977; López, 1978; Uieda, 1984; Meschiatti, 1995; Bertaco et al., 1998). This behavior and the observed consumption of seeds suggest that these species could be potential plant dispersers, particularly for macrophytes, as terrestrial plant species present a wide range of possibly more efficient seed dispersal mechanisms. The role of fish as seed dispersers is still to be investigated in Atlantic Forest fish species, and seed viability studies would be necessary to determine if Astyanax species act as seed dispersers or predators, as well as the relative importance of ichthyochory in comparison to other dispersal mechanisms for the plant species envolved.

\section{ACKOWLEDGEMENTS}

We are grateful to Bruno Irgang (Dep. Botânica UFRGS), Inga Mendes, Nora Fortes and Gilson Moreira (Dep. Zoologia UFRGS) for help with the identification of food items, and Mariana Corrêa, Clarice Fialho (Dep. Zoologia, UFRGS) and Virgínia Uieda (UNESP) for critical comments and revision of the manuscript.

\section{RESUMO}

Seis espécies do gênero Astyanax, presentes no rio Maquiné, RS, foram estudadas quanto aos seus hábitos alimentares. Os exemplares foram amostrados bimensalmente de novembro de 1995 a setembro de 1996 nas zonas ritral e potamal do rio. Os itens alimentares foram identificados e quantificados de acordo com uma escala semiquantitativa de abundância, utilizando-se para análise a frequência de ocorrência e um índice de importância alimentar para cada espécie e zona do rio. Análises multivariadas de agrupamento e ordenação foram utilizadas para comparar as dietas intra e interespecíficas. Todas as espécies foram consideradas onivoras, sendo que os itens mais importantes foram os insetos e restos de vegetais superiores. Sugere-se que as espécies estudadas possam atuar como dispersoras de sementes, particularmente para macrófitas. Diferenças espaciais intraespecíficas não foram encontradas, exceto para A. fasciatus. A presença de Podostemaceae no curso médio do rio parece ser uma fonte importante de alimento para as espécies, além de servir de refúgio para diversos organismos que são predados por Astyanax sp.

\section{REFERENCES}

Araújo-Lima, C. A. R. M.; Agostinho, A. A. and Fabré, N. M. (1995), Trophic aspects of fish communities in Brazilian rivers and reservoirs. In - J. G. Tundisi; C. E. M. Bicudo and T. Matsumura-Tundisi (eds.). Limnology in Brazil. Rio de Janeiro : ABC/SBL. pp. 105-136.

Arcifa, M. S.; Northcote, T. G. and Froehlich, O. (1991), Interactive ecology of two cohabiting characin fishes (Astyanax fasciatus and Astyanax bimaculatus) in an eutrophic Brazilian reservoir. Journal of Tropical Ecology, 7, 257-268.

Austen, D. J.; Bayley, P. B. and Menzel, B. W. (1994), Importance of the guild concept to fisheries research and management. Fisheries, 19, 12-18.

Baptista, D. F.; Dorvillé, L. F. M.; Buss, D. F.; Nessimian, J. L. and Soares, L. H. J. (1998a), Distribuição de Comunidades de Insetos Aquáticos no Gradiente longitudinal de uma Bacia Fluvial do Sudeste Brasileiro. In - J. L. Nessimian and A. L. Carvalho (eds.). Ecologia de Insetos Aquáticos. Programa de Pós-Graduação em Ecologia da UFRJ. Rio de Janeiro. (Séries Oecologia Brasiliensis; 5). pp. 191-207. 
Baptista, D. F.; Buss, D. F.; Dorvillé, L. F. M. and Nessimian, J. L. (1998b), O Conceito de Continuidade de Rios é Válido para Rios de Mata Atlântica no Sudeste do Brasil ? In - J. L. Nessimian and A. L. Carvalho (eds.). Ecologia de Insetos Aquáticos. Programa de Pós-Graduação em Ecologia da UFRJ. Rio de Janeiro. (Séries Oecologia Brasiliensis; 5). pp. 209-222.

Barbosa, P. M. M. and Matsumura-Tundisi, T. (1984), Consumption of zooplanktonic organisms by Astyanax fasciatus Cuvier, 1819 (Osteichthyes, Characidae) in Lobo (Broa) Reservoir, São Carlos, SP, Brazil. Hydrobiologia, 113, 171-181.

Bertaco, V. A.; Lucena, Z. M. S. and Becker, F. G. (1998), Variação espacial e temporal na abundância de Astyanax bimaculatus e Astyanax fasciatus (Characidae) no lago Guaíba, Rio Grande do Sul, Brasil. Comun. Mus. Ci. PUCRS. (Série Zool.; 11). pp. 61-89.

Costa, W. J. (1987), Feeding habitats of a fish community in a tropical coastal stream, Rio Mato Grosso, Brazil. Stud. Neotrop. Fauna Envirom., 22, 145-153.

Crampton, W. G. R. (1999), Os peixes da Reserva Mamirauá: diversidade e história natural da planície alagável da Amazônia. In - Queiroz, H. L. and Crampton, W. G. R. (eds.). Estratégias para o manejo de recursos pesqueiros em Mamirauá. CNPq, Sociedade Civil Mamirauá, Brasília. pp. 10-36.

Edwards, R. J. (1977), Seasonal migrations of Astyanax mexicanus as na adaptation to novel environments. Copeia, 707-771.

Escalante, A. H. (1982), Contribuicion al conocimiento de las relaciones troficas de peces de agua dulce del area platense. I. Astyanax eigenmanniorum (Ostheichthyes tetragonopteridae). Limnobios, 2, 311- 322

Esteves, K. E. (1996), Feeding ecology of three Astyanax species (Characidae, Tetragonopterinae) from a floodplain lake of Mogi-Guaçú River, Paraná River Basin, Brazil. Env. Biol. Fish., 46, 83-101.

Esteves, K. E. and Galetti Jr., P. M. (1995), Food partitioning among some characids of a small Brazilian floodplain lake from the Paraná River basin. Env. Biol. Fish., 42, 375-389.

Faria, A. P. and Marques, J. S. (1999), O desaparecimento de pequenos rios brasileiros. Ciência Hoje, 148, 56-61.

Fugi, R. (1998), Ecologia alimentar de espécies endêmicas de lambaris do trecho médio da bacia do rio Iguaçu. PhD Thesis. Universidade Federal de São Carlos, São Paulo, Brazil.

Garutti, V. and Britski, H. A. (1997), Descrição de uma espécie nova de Astyanax (Teleostei, Characidae), com mancha umeral horizontalmente ovalada, da Bacia do Rio Guaporé, Amazônia. Papéis Avulsos de Zoologia, 40, 217-229.
Gelwick, F. P. and Matthews, W. J. (1996), Trophic relations of stream fishes. In - Hauer, F. R. and Lamberti, G. A. (eds.). Methods in Stream Ecology. San Diego : Academic Press,. pp. 475-492.

González, A.; Molla, F. H. and Arredondo, I. R. (1986), Biologia de la sardina de rio Astyanax bimaculatus (Linnaeus, 1758) (Pisces: Characidae) del rio Cancamure, Estado Sucre, Venezuela. I. Contenido estomacal. Bol. Inst. Oceonogr. Venezuela, 25, 107114.

Gottsberger, G. (1978), Seed Dispersal by Fish in the Inundated Regions of Humaitá, Amazonia. Biotropica, 10, 170-183.

Goulding, M. (1980), The fishes and the forest. Berkeley : University of California Press.

Goulding, M.; Carvalho, M. L. and Ferreira, E. G. (1988), Rio Negro: rich lige in poor water. SPB Academic Publishing, The Hague.

Granado-Lorencio, C. and Garcia-Novo, F. (1986), Feeding habits of the fish community in a eutrophic reservoir in Spain. Ekol. Pol., 34, 95-110.

Guillen, E. and Granado, C. (1984), Alimentacion de la ictiofauna del embalse de Torrejon (rio Tajo, Caceres). Limnética, 1, 304-310.

Hartz, S. M.; Silveira, C. M. and Barbieri, G. (1996), Alimentação das espécies de Astyanax Baird and Girard, 1854 ocorrentes na lagoa Caconde, RS, Brasil (Teleostei, Characidae). Revista UNIMAR, 18, 269-281.

Hyslop, E. J. (1980), Stomach contents analysis: a review of methods and their application. J. Fish Biol., 17, 411-429.

Jin, S. M and Toledo, V. (1975), Citogenética de Astyanax fasciatus e Astyanax bimaculatus (Characidae, Tetragonopterinae). Ciência e Cultura, 27, 1122-1124.

Kubitzki, K. (1985), Ichthyochory in Gnetum venosum. An. Acad. Bras. Ci., 57, 513-516.

Kubitzki, K. and Ziburaki, A. (1993), Seed Dispersal in Flood Plain Forests of Amazonia. Biotropica, 26, 30-43.

López, M. I. (1978), Migración de la sardina Astyanax fasciatus (Characidae) en el río Tempis que, Guanacaste, Costa Rica. Rev. Biol. Trop., 26, 261-275.

Luiz, E. A.; Agostinho, A. A.; Gomes, L. C. and Hahn, N. S. (1998), Ecologia trófica de peixes em dois riachos da bacia do rio Paraná. Rev. Brasil. Biol., 58: 273-285.

Menezes, N. A., Castro, R. M. C., Weitzman, S. H. and Weitzman, M. J. (1990), Peixes de riacho da floresta costeira attlântica brasileira: um conjunto pouco conhecido e ameaçado de vertebrados. In - Annals of the II Simpósio de Ecossistemas da Costa Sul e Sudeste do Brasil, Águas de Lindóia. pp. 290-295.

Meschiatti, A. J. (1995), Alimentação da comunidade de peixes de uma lagoa marginal do rio Mogi-Guaçu, SP. Acta Limnologica Brasiliensia, 7, 115-137. 
Moreira-Filho, O. and Bertollo, L. A. C. (1991), Astyanax scabripinis (Pisces, Characidae) : a species complex. Rev. Bras. Genet., 14, 331-357.

Myers, N.; Mittermeier, R. A. ; Mittermeier, C. G.; Fonseca, G. A. and Kent, J. (2000), Biodiversity hotspots for conservation priorities. Nature, 403, 853-858.

Nomura, H. (1975), Alimentação de três espécies do gênero Astyanax Baird and Girard, 1854 (Osteichthyes, Characidae) no rio Mogi Guaçu, SP. Rev. Brasil. Biol., 35, 595-614.

Philbrick, C.T. and Novelo, A. (1997), Ovule number, seed number and size in Mexican and North American species of Podostemaceae. Aquatic Botany, 57, 183-200.

Pillar, V. de P. (1997), Multivariate exploratory analysis and randomization testing with multiv (software abstract). Coenoses, 12, 145-148.

Rosa, R. S. and Menezes, N. A. (1996), Relação preliminar das espécies de peixes (Pisces, Elasmobranchii, Actinopterygii) ameaças no Brasil. Rev. bras. Zool., 13, 647-667.

Sabino, J. and Castro, R. C. (1990), Alimentação, período de atividade e distribuição espacial dos peixes de um riacho da floresta atlântica (sudeste do Brasil). Rev. Brasil. Biol., 50, 23-36.

Sabino, J. and Zuanon, J. (1998), A stream fish assemblage in Central Amazonia: distribution, activity patterns and feding behavior. Ichthyol. Explor. Freshwaters, 8, 201-210.

Santos, G. M.; Pinto, S. S. and Jegu, M. (1997), Alimentação do pacu-cana Mylesinus paraschomburgkii (Teleostei, Serrasalmidae) em rios da amazônia brasileira. Rev. Brasil. Biol., 57, 311-315.

Santos, G. M. and Rosa, P. S. (1998), Alimentação de Anostomus ternetzi e Synaptolaemus cingulatus, duas espécies de peixes amazônicos com boca superior. Rev. Brasil. Biol., 58, 255-262.
Sazima, I. (1986), Similarities in feeding behavior between some marine and freshwater fishes in two tropical communities. J. Fish. Biol., 29, 53-65.

Souza-Stevaux, M. C.; Negrelle, R. R. B. and Citadini-Zanette, V. (1994), Seed dispersal by the fish Pterodoras granulosus in the Paraná River Basin, Brazil. Journal of Tropical Ecology, 10, 621-626.

Takagi, Y.; Hirano, T. and Yamada, J. (1989), Scale regeneration of Tilapia (Oreochromis niloticus) under various ambient and dietary calcium concentrations. Comp. Biochem. Physiol., 92A, 605-608.

Teixeira, R. L. (1989), Aspectos da ecologia de alguns peixes do arroio Bom Jardim, Triunfo-RS. Rev. Brasil. Biol., 49, 183-192.

Uieda, V. (1984), Ocorrência e distribuição dos peixes em um riacho de água doce. Rev. Brasil. Biol., 44, 203-213.

Uieda, V. and Kikuchi, R. (1995), Entrada de material alóctone (detritos vegetais e invertebrados terrestres) num pequeno curso de água corrente na cuesta de botucatu, São Paulo. Acta Limnologica Brasiliensia, 7, 105-114.

Uieda, V.; Buzzato, P. and Kikuchi, R. (1997), Partilha de recursos alimentares em peixes em um riacho de serra do Sudeste do Brasil. An. Acad. Bras. Ci., 69, 243-252.

Vannote, R. L.; Minshall, G. W.; Cummins, K. W.; Seddel, J. R. and Cushing, C. E. (1980), The River Continuum Concept. Canadian Journal of Fisheries and Aquatic Sciences, 37, 130-137.

Zaret, T. M. and Rand, A. S. (1971), Competition in tropical stream fishes: support fr the competitive exclusion principle. Ecology, 52, 336-339.

Received: August 15, 2000;

Revised: March 30, 2001; Accepted: September 26, 2001. 